ISSN 2075-9827 e-ISSN 2313-0210

Carpathian Math. Publ. 2019, 11 (2), 418-421

doi:10.15330/cmp.11.2.418-421

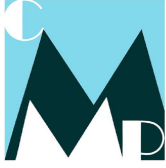

http://www.journals.pnu.edu.ua/index.php/cmp

Карпатські матем. публ. 2019, Т.11, №2, С.418-421

PONOMARCHUK B.S.

\title{
METRIC DIMENSION OF METRIC TRANSFORM AND WREATH PRODUCT
}

\begin{abstract}
Let $(X, d)$ be a metric space. A non-empty subset $A$ of the set $X$ is called resolving set of the metric space $(X, d)$ if for two arbitrary not equal points $u, v$ from $X$ there exists an element $a$ from $A$, such that $d(u, a) \neq d(v, a)$. The smallest of cardinalities of resolving subsets of the set $X$ is called the metric dimension $m d(X)$ of the metric space $(X, d)$.

In general, finding the metric dimension is an NP-hard problem. In this paper, metric dimension for metric transform and wreath product of metric spaces are provided. It is shown that the metric dimension of an arbitrary metric space is equal to the metric dimension of its metric transform.

Key words and phrases: metric dimension, metric transform, wreath product.
\end{abstract}

National University of Kyiv-Mohyla Academy, 2 Skovorody str., 04070, Kyiv, Ukraine

E-mail: ponomarchuk .bogdanegmail.com

\section{INTRODUCTION}

Let $(X, d)$ be a metric space. It is said that a set $A$ is the resolving set of the metric space $(X, d)$ if $A$ is a non-empty subset of $X$ and for an arbitrary different points $u, v$ from $X$ there exists an element $a$ in $A$, such that distances $d(u, a)$ and $d(v, a)$ are not equal. The smallest of cardinalities of resolving subsets of the set $X$ is called the metric dimension $m d(X)$ of the metric space $(X, d)$.

Definition of the metric dimension for metric spaces was firstly introduced by Blumenthal in 1953 [4]. 20 years later Harari and Melter in [7] applied it to the graphs. After that the metric dimension concept found range of applications, like in combinatorial analysis, robotics, for finding its location, biology, chemistry etc. [14], [9], [13].

In 2013 S. Bau and F. Beardon [2] got the Blumenthal's ideas and proceeded research of the metric spaces metric dimension. They has managed to calculate the metric dimension of the sphere in a k-dimensional Euclidean space. Later, M. Heydarpour and S. Maghsoudi in [8] calculated the metric dimensions of geometric spaces.

As well as metric dimension, Blumenthal has also described metric transforms [3], which was studied further by other researchers, like by Schoenberg and von Neumann in scope of Euclidian subspace metric transforms into Hilbert space subsets [12], [15].

In general, finding of the metric dimension of a finite graph is an NP-hard problem [6]. Following that, metric dimension characterization for a finite metric space is also NP-hard. This is why there are several ways of conducting metric dimension research. One of those is researching metric dimension of constructions of two graphs, if we know metric dimensions of both of them. For example, metric dimensions of wreath products and cartesian products of two finite graphs characterized in [5], [1].

$\mathrm{y} \Delta \mathrm{K} 519.1$

2010 Mathematics Subject Classification: 05C12, 51K05, 54 E35.

(C) Ponomarchuk B.S., 2019 
In this paper we characterize metric dimensions of the wreath products of metric spaces which were considered in [11], [10]. This construction of metric spaces was called a wreath product because the isometry group of the wreath product of metric spaces is isomorphic to the wreath product of theirs isometry groups. In particular, we will also show that metric dimension of the metric transform of an arbitrary metric space is equal to the metric dimension of this space.

\section{METRIC TRANSFORM}

Denote by $\mathbb{R}^{+}$the set of all non-negative real numbers. Let $s$ be a continuous monotone increasing function and $s(0)=0$. Such functions are called scales. Transformation of metric space $\left(X, d_{X}\right)$ is the space $\left(X, s\left(d_{X}\right)\right)$, where function $s\left(d_{X}\right)$ might not follow triangle inequality [3]. Transformation is called metric, if $s\left(d_{X}\right)$ is metric.

Definition 1 ([3]). If for metric spaces $\left(X, d_{X}\right)$ and $\left(Y, d_{Y}\right)$ there is a bijection $g: X \rightarrow Y$, and scale $s$ that for arbitrary $u, v \in X$ holds:

$$
d_{X}(u, v)=s\left(d_{Y}(g(u), g(v))\right)
$$

then such metric spaces are called isomorphic.

Proposition 1. Let $(X, d)$ be a metric space and let $s: \mathbb{R}^{+} \rightarrow \mathbb{R}^{+}$be a metric transform. Then metric basis of $X$ is also the metric basis of the metric transform $(X, s(d))$.

Proof. Let $V=\left\{v_{i}, i \in I\right\}$ be a metric basis of the space $(X, d)$. As follows from the definition of a metric basis, for every $u, w \in X$ there is $v_{j} \in V$, such that

$$
d\left(u, v_{j}\right) \neq d\left(w, v_{j}\right)
$$

i. e. $v_{j}$ resolves points $u$ and $w$. The function $s$ is monotone increasing, so, we have

$$
s\left(d\left(u, v_{j}\right)\right) \neq s\left(d\left(w, v_{j}\right)\right) .
$$

Hence, $v_{j}$ resolves $u$ and $w$ in $(X, s(d))$. Therefore, $V$ is resolving set of $(X, s(d))$.

We need to show, that $V$ is minimal cardinality. Assume, that there is $v_{l}$, such that $V \backslash\left\{v_{l}\right\}$ also is a resolving set of $(X, s(d))$. But $V$ is a minimal resolving set of $(X, d)$. Hence, there are points $u, w \in X$ such that for any $v_{j} \in V \backslash\left\{v_{l}\right\}$ the following condition holds:

$$
d\left(u, v_{j}\right)=d\left(w, v_{j}\right)
$$

But it means, that $s\left(d\left(u, v_{j}\right)\right)=s\left(d\left(w, v_{j}\right)\right)$. Hence, $V \backslash\left\{v_{l}\right\}$ is not a metric basis of $(X, s(d))$.

Corollary 1. Metric dimension of a metric space $(X, d)$ is equal to the metric dimension of its metric transform $(X, s(d))$ for any scale $s$. 


\section{WREATH PRODUCT}

First, we recall the construction of a wreath product of metric spaces.

Definition 2. A metric space $(X, d)$ is called uniformly discrete if for an arbitrary $u, v \in X$ either $u=v$ or there exists a radius $r>0$ such that $d(u, v)>r$.

Let $\left(X, d_{X}\right)$ be a uniformly discrete metric space, and $\left(Y, d_{Y}\right)$ be a bounded metric space. Since space $\left(X, d_{X}\right)$ is uniformly discrete, then there exists $r$ such that for two different arbitrary points $x_{1}, x_{2}$ from set $X$ inequality $d_{X}\left(x_{1}, x_{2}\right) \geq r$ holds. Let $s(x)$ be the scale such that

$$
\operatorname{diam}(s(Y))<r
$$

Let us define a function $\rho_{s}$ on the Cartesian product $X \times Y$ by:

$$
\rho_{s}\left(\left(x_{1}, y_{1}\right),\left(x_{2}, y_{2}\right)\right)= \begin{cases}d_{X}\left(x_{1}, x_{2}\right), & \text { if } x_{1} \neq x_{2} \\ s\left(d_{Y}\left(y_{1}, y_{2}\right)\right), & \text { if } x_{1}=x_{2}\end{cases}
$$

Such a metric space is called wreath product of metric spaces $\left(X, d_{X}\right)$ and $\left(Y, d_{Y}\right)$ and denoted as $X w r_{s} Y$ [11]. For different scales $s_{1}$ and $s_{2}$ metric spaces $X w r_{s_{1}} Y$ and $X w r_{s_{2}} Y$ are isomorphic.

Theorem 1. Let $X$ be a finite metric space and $Y$ be a bounded metric space, $m d(Y)<\infty$. Then, the dimension of wreath product of metric spaces $\left(X, d_{X}\right)$ and $\left(Y, d_{Y}\right)$ is equal to

$$
m d\left(X w r_{s} Y\right)=|X| * m d(Y) .
$$

If $m d(Y)=\infty$, then $\operatorname{md}\left(X w r_{s} Y\right)=\infty$.

Proof. Let $v_{1}, \ldots, v_{l}$ be a metric basis of $\left(Y, d_{Y}\right)$. We assume that $X=\left\{x_{1}, \ldots, x_{m}\right\}$. Define a set

$$
B=\left\{\left(x_{j}, v_{i}\right) \mid 1 \leq j \leq m, 1 \leq i \leq n\right\} .
$$

We need to show that the set $B$ is a basis of $X w r_{s} Y$.

Let $\left(x_{1}, y_{1}\right)$ and $\left(x_{2}, y_{2}\right)$ be two different points of $X w r_{s} Y$. From the definition of the wreath product of metric spaces follows, that if $x_{1} \neq x_{2}$, then points $\left(x_{1}, y_{1}\right)$ and $\left(x_{2}, y_{2}\right)$ are resolved by point $\left(x_{2}, v_{2}\right)$. Indeed, we will have:

$$
\rho\left(\left(x_{1}, y_{1}\right),\left(x_{2}, y_{2}\right)\right)=d_{X}\left(x_{1}, x_{2}\right), \quad \rho\left(\left(x_{2}, y_{2}\right),\left(x_{2}, v_{2}\right)\right)=s\left(d_{Y}\left(y_{2}, v_{2}\right)\right) .
$$

From inequality (1) follows, that

$$
\rho\left(\left(x_{1}, y_{1}\right),\left(x_{2}, y_{2}\right)\right)<\rho\left(\left(x_{2}, y_{2}\right),\left(x_{2}, v_{2}\right)\right)
$$

and therefore points $\left(x_{1}, y_{1}\right)$ and $\left(x_{2}, y_{2}\right)$ are resolved by $\left(x_{2}, v_{2}\right)$.

Let $x_{1}=x_{2}$. In this case, since $v_{1}, \ldots, v_{n}$ is the metric basis of $Y$, exists $v_{j}$ that resolves $y_{1}$ and $y_{2}$. Then

$$
\rho\left(\left(x_{1}, y_{1}\right),\left(x_{1}, v_{j}\right)\right)=s\left(d_{Y}\left(y_{1}, v_{j}\right)\right), \quad \rho\left(\left(x_{2}, y_{2}\right),\left(x_{1}, v_{j}\right)\right)=s\left(d_{Y}\left(y_{2}, v_{j}\right)\right) .
$$

Since $v_{j}$ resolves $y_{1}$ and $y_{2}, s\left(d_{Y}\left(y_{1}, v_{j}\right)\right) \neq s\left(d_{Y}\left(y_{2}, v_{j}\right)\right)$. In this case all elements from the set $X$ are supposed to be included into a basis of the cartesian product.

And now let us show that $B$ is a basis. Assume that $B^{\prime}=B /\left\{x_{1}, v_{1}\right\}$ is a basis. Since $v_{1}, \ldots, v_{n}$ is the basis of the metric space $Y$, then there exists $y_{1}, y_{2} \in Y$ which are not resolved by $v_{2}, v_{3}, \ldots, v_{n}$ but are resolved by $v_{1}$ only. Then points $\left(x, y_{1}\right)$ and $\left(x, y_{2}\right)$ are not resolved by points from $B^{\prime}$. This means that $B$ is the minimal set, therefore $B$ is a metric basis of the space $X w r_{s} Y$.

As a result we have that $m d\left(X w r_{s} Y\right)=|X| m d(Y)$.

Theorem 1 implies the next statement.

Corollary 2. If the space $X$ is infinite, then $m d\left(X w r_{s} Y\right)=\infty$. 


\section{REFERENCES}

[1] Assiyatun H., Bača M., Baskoro E.T., Salmana A.N.M., Saputro S.W., Simanjuntak R., Uttunggadewaa S. The metric dimension of the lexicographic product of graphs. Discr. Math. 2013, 313, 1045-1051. doi: 10.1016/j.disc.2013.01.021

[2] Bau S., Beardon A.F. The Metric Dimension of Metric Spaces. Comput. Methods Funct. Theory 2013, 13, 295305. doi:10.1007/s40315-013-0024-0

[3] Blumenthal L.M. Remarks concerning the euclidean four-point property. Ergebnisse Math. Kolloq. 1936, 7, 7-10.

[4] Blumenthal L.M. Theory and applications of distance geometry. Clarendon Press, Oxford, 1953.

[5] Chau K., Gosselin S. The metric dimension of circulant graphs and their cartesian products. Opuscula Math. 2017, 37 (4), 509-534. doi:10.7494/OpMath.2017.37.4.509

[6] Garey M.R., Johnson D.S. Computers and intractability. A guide to the theory of NP-completeness. W. H. Freeman and Company, New York, 1979.

[7] Harary F., Melter R.A. On the metric dimension of a graph. Ars Combin. 1976, 2, 191-195.

[8] Heydarpour M., Maghsoudi S. The metric dimension of geometric spaces. Topology Appl. 2014, 178, $230-235$. doi:10.1016/j.topol.2014.09.012

[9] Khuller S., Raghavachari B., Rosenfeld A. Landmarks in graphs. Discrete Appl. Math. 1996, 70, $217-219$. doi:10.1016/0166-218X(95)00106-2

[10] Oliynyk B. Infinitely iterated wreath products of metric spaces. Algebra Discrete Math. 2013, 15 (1), 48-62.

[11] Oliynyk B. Wreath product of metric spaces. Algebra Discrete Math. 2007, 4, 123-130.

[12] Schoenberg I.J. Metric spaces and completely monotone functions. Ann. of Math. 1938, 39, 811-841. doi: $10.2307 / 1968466$

[13] Sebo A., Tannier E. On Metric Generators of Graphs. Math. Oper. Res. 2004, 29, 383-393. doi:10.1287/moor.1030.0070

[14] Slater P.J. Leaves of trees. Congr. Numer. 1975, 14, 549-559.

[15] Von Neumann J., Schoenberg I.J. Fourier integrals and metric geometry. Trans. Amer. Math. Soc. 1941, 50, 226251. doi:10.2307/1989957

Received 28.08.2019

Пономарчук Б.С. Метрична розмірність метричної трансформачї̈ та вінцевого добутку // Карпатські матем. публ. - 2019. - Т.11, №2. - С. 418-421.

$\Delta \wedge я$ довільного метричного простору $(X, d)$ множина $A \subset X$ називається розділяючою, якщо для довільних різних елементів $u, v$, що належать множині $X$ існує такий елемент $a \in$ $A$, що відстані $d(a, u)$ та $d(a, v) \in$ різними. Метричною розмірністю $m d(X)$ простору $(X, d)$ називається розділяюча множина найменшої потужності.

В загальному випадку пошук метричної розмірності $€$ NP-важкою задачею. В роботі охарактеризовано метричну розмірінсть метричної трансформації та вінцевого добутку метричних просторів. Також показано, шо метрична розмірність довільного метричного простору співпадає з метричною розмірністю його метричної трансформації.

Ключові слова і фрази: метрична розмірність, метрична трансформація, вінцевий добуток. 